\title{
Z TEOLOGII ŻYCIA ZAKONNEGO
}

Życie zakonne doby obecnej znalazło się w sytuacji swoistego paradoksu. Doczekawszy się na Soborze Watykańskim II uroczystej sankcji Kościoła zaszeregowującej je do składowych elementów jego własnej tajemnicy, w praktyce, w konkrecie kościelnego życia przeżywa jeden z wyjątkowo ostrych kryzysów, wyrażający się bolesnym poczuciem zagubienia tych, którzy znaležli się w jego orbicie i gwałtownym spadkiem liczby tych, którzy chcieliby w orbicie tej się znaleźć. Daje to wszystko sporo do myślenia: ukazuje z jednej strony nowe, niedostrzegane dotąd perspektywy skomplikowanego i ciągle dalekiego od zadowalającego teoretycznego ujęcia życia zakonnego, a z drugiej stawia wobec konieczności konkretnych przemyśleń, prowadzących do skutecznego zaradzenia przedłużającemu się i kto wie czy nie pogłębiającemu się kryzysowi. Zamierzeniem niniejszego artyłulu jest próba głębszego spenetrowania treści życia zakonnego poprzez analizę jego powiązań z tajemnicą Kościoła. Ten kąt widzenia $w$ badaniu tajemnicy życia zakonnego, wydaje się byé na naszym zwałaszcza polskim terenie nakazem chwili. Zainteresowanie bowiem życiem zakonnym skupia się, jeżeli tak można powiedzieć, na tajemnicy życia zakonnego samej w sobie, w izolacji od jej teologicznego i życiowego kontekstu. Dało to w efekcie szeroko rozbudowaną teorię życia zakonnego jako takiego, ale teorię, która nie utożsamia się z pełna i rzeczywista prawdą o powolaniu zakonnym w Kościele. Dostrzega to wspólczesna teologia życia zakonnego i idąc za wyraźnymi wskazaniami nauki soborowej, bardzo żywo interesuje się tym właśnie powiązaniem jego z życiem i strukturą Kościoła ${ }^{1}$, hołdując słusznemu przekonaniu, że stanowi to drogę wyjścia z przedłużającego się niepokojąco kryzysu tej

1 Por. J. Daniélou, La place des religieux dans la structure de l'Église, w: L'Eglise de Vatican II, Paris 1966, t. III, 1172-1180; G. Martelet, Sainteté de l'Eglise et vie religieuse, Toulouse 1964 . 
formy życia chrześcijańskiego. Dopiero widziane w perspektywie eklezjalnej życie zakonne ukazuje się w całym niewymownym bogactwie i płynącą z niego autentyczną siłą pociągającą.

\section{PROBLEM ISTOTY ZYCIA ZAKONNEGO}

Życie zakonne od początku prawie obecne w życiu Kościoła, przeżywane na różne sposoby, a przecież zawsze w pewnych istotnych pierwiastkach takie samo, na ostatnim Soborze doczekaio się nie tylko umieszczenia we wnętrzu jego struktury, ale oficjalnego skodyfikowania w osobnym dokumencie soborowym, jakim jest Dekret Perfectae Caritatis ${ }^{2}$. Po raz pierwszy więc $w$ dziejach Kościoła definitywnie wyjaśnione zostały podstawowe problemy życia zakonnego. W zakresie więc tego, co można by określić jako katolicką teorię życia zakonnego, po tak miarodajnym wystąpieniu Urzędu Nauczycielskiego spodziewać by się należało, że istnieje stan pełnej klarowności i jednoznacznej pewności. Rzeczywistość jednak jest zgoła inna. Teologia życia zakonnego znalazła się jak nigdy w stanie ostrej krytycznej analizy ${ }^{3}$. Wnikliwemu badaniu poddano niemal wszystko od istoty życia zakonnego poczynając, a na jego głównych elementach składowych kończąc ${ }^{4}$. Nie oznacza to bynajmniej ich kwestionowania, podawania w wątpliwość rảcji istnienia, jest to niepokój poszukiwania pełnej i pogłębionej teologicznie syntezy. Los ten dzielą i inne wielkie działy katolickiej teologii i to takie nawet, które wydawało się, że już dawno osiągnęly stan ostatecznej stabilizacji i dojrzałości, żeby wymienić tylko chrystologię i teologię kapłaństwa. Ten niepokój poszukiwania zdaje się być zjawiskiem koniecznym, jeżeli nie naturalnym, ale na terenie powołania zakonnego jest chyba jednym $z$ głównych powodów przedłużającego się stanu niepewności i kryzysu.

W stanie żywej kontrowersji znajduje się przede wszystkim sama istota $\mathrm{i}$ rdzeń powołania zakonnego ${ }^{5}$. Mimo magistralnych wypowiedzi Lumen Gentium i Perfectae Caritatis ${ }^{6}$, teologia współczesna nie może się zdecydować, który z bezspornie zaangażowanych w powołaniu zakonnym pierwiastków uznać za istotny i decydujący o być lub nie być tegoż po-

2 Cennym uzupełnieniem dwu dokumentów soborowych jest ekshortacja $\mathrm{Pa}$ wła VI, Evangelica testificatio z dnia 29 czerwca 1971.

3 Wartościowy przegląd bibliograficzny literatury na ten temat podaje A. Favale, Per una presenza viva dei religiosi nella Chiesa e nel mondo, Torino 1970, 889-930. Por. także, La vie religieuse dans l'Eglise du Christ, Paris 1964, a zwłaszcza zawarty tam artykuł $\mathrm{R}$. Carpentier, Vers une théologie de la vie religieuse, 33-78.

${ }^{4}$ Przejrzyście ukazuje to T. Matura w bardzo popularnej swego czasu publikacji: La vie religieuse au tournant, Paris 1971.

s Por. j. w., 36 nn.

${ }_{6}$ Jak zauważa jeden z najwybitniejszych znawców teologii życia zakonnego J. Galot, Sobór świadomie uchylił się w Dekrecie Perfectae Caritatis od definiowania życia zakonnego ze względu na jego (dekretu) pastoralny charakter. Por. Renouveau de la vie consacrée, Paris 1966, 47. 
wołania. Sobór zdaje się eksponować element konsekracji i naśladowania Chrystusa ${ }^{7}$, ale przecież i jedno i drugie stanowi dziedzictwo i program życiowy każdego chrześcijanina. Jedna grupa teologów byłaby skłonna podtrzymać dość powszechnie w przeszłości lansowaną opinię o powołaniu do realizacji rad ewangelicznych, jako pierwiastku formalnym życia zakonnego ${ }^{8}$. Dla innych pierwiastek ten stanowi radykalizm $w$ realizacji ewangelii, celibat i związane z tym życie we wspólnocie, szczególna służba Kościołowi czy ludziom, czy wreszcie realizacja ideału osobistej doskonałości ${ }^{9}$. Faktem jest, że wymienione pierwiastki stanowią niewątpliwie elementy składowe autentycznego życia zakonnego do tego stopnia, że gdyby w nim któregoś zabrakło, trudno byłoby mówić o jego prawdziwej, chrześcijańskiej postaci. Ale prawdą jest także $i$ to, że w obecnym stanie rzeczy jest niezmiernie trudno, o ile nie wręcz niemożliwe, ustalenie bezspornej i wyłącznej preponderancji któregoś z tych pierwiastków w całokształcie struktury życia zakonnego. W takiej sytuacji wydaje się więc, że zrezygnować należy z rozstrzygnięcia tego akademickiego raczej sporu o to, który z elementów składowych życia zakonnego uznać trzeba za decydujący o jego istocie, a całą uwagę skierować na stworzenie z nich harmonijnej syntezy, w której powiązanie z tajemnicą Kościoła znajdzie właściwe uwzględnienie.

\section{W POSZUKIWANIU SYNTEZY}

Punktem wyjścia wysiłków zmierzających do syntetycznego ujęcia soborowej nauki o powołaniu zakonnym i jego specyfice jest po raz pierwszy z takim naciskiem w nauczaniu kościelnym uwypuklony fakt konsekracji, a więc wyłącznego przeznaczenia i prżynależności zakonnika d’o Boga. Konstytucja o Kościele i Dekret nie pozostawiają w tej mierze miejsca na żadną wątpliwość: w życiu zakonnym ostatecznym ale i najbliższym celem jest „oddanie się na służbę Bożą” i ,życie dla samego Boga" 10, „oddanie się... na własność umiłowanemu nade wszystko Bogu" 11. Obydwa dokumenty wiążą wyraźnie te konsekwencje z tajemnicą chrztu i wynikającego stąd ogólnochrześcijańskiego zakonsekrowania, ale nie zamierzają równocześnie ukrywać wynikającej z tego faktu poważnej trudności, jaką stanowi wzajemny stosunek tych dwu konsekracji. Fundamentalna bowiem konsekracja będąca bezpośrednio konsekwencją chrztu, w istocie swojej powoduje to samo, czyni bowiem z ochrzczonych

7 L. G. r. VI. nr 44; P. C. nr 1. Por. J. MI. R. Tillard, Les grandes lois de la renovation de la vie religieuse, w: Vatican II. L'adaptation et la renovation de la vie religieuse, Paris 1967, 98-99.

8 Por. T. Matura, dz. cyt., 45 n.; R. Carpentier, art. cyt., 63-65.

9 J. w., $47-52$.

10 P. C. $\mathrm{nr} 3$.

11 L. G. nr 44. 
ludzi będących Bożą własnością, zdatnych i zobowiązanych do oddawania Bogu godnej jego majestatu czci 12. Jeżeli więc życie zakonne posiadać ma w Kościele sens, trzeba wskazać na jakiś szczególny wzgląd, jakąs szczególną rację, która by ten sens ukazywała i określała. Sprawa nie jest prosta i powiedzmy otwarcie, że i próba wskazania ra te racje przez obydwa dokumenty soborowe, pozostawia wrażenie pewnego niedosytu. Dekret Perfectae Caritatis ogranicza się do ogólnikowego nazwania konsekracji zakonnej ,jakąś szczególną konsekracją”, wynikającą z faktu oddania przez zakonników „całego życia na służbę Bogu" 13. Konstytucja o Kościele idzie dalej w wyjaśnieniu wzajemnego stosunku obydwu konsekracji i odrębność konsekracji zakonnej widzi w sytuacji większej efektywności osiągnięcia ostatecznego celu z racji zastosowania skuteczniejszych środków ${ }^{14}$. Śluby więc zakonne stwarzają korzystniejsze warunki do przeciwstawienia się głównym przeszkodom stojącym na drodze do realizacji ostatecznego celu, jakimi są egoizm i umiłowanie świata ${ }^{15}$. Oznacza to więc, że odrębność konsekracji zakonnej w stosunku do konsekracji chrzcielnej usytuowana została nie w płaszczyźnie celu, ale w płaszezyźnie środków do osiągnięcia tego celu pewniej prowadzących ${ }^{16}$. Stanowi to niewątpliwie cenne wyjaśnienie trudnego zagadnienia, ale trudno je uznać za w pełni zadowalające, nie wyjaśnia bowiem kolejnej trudności związanej z pozorami uprzywilejowania zakonników w realiza. cji celu, przy użyciu specjalnych środków. W rzeczy samej nie da się za.przeczyć, że zakonnicy z racji swojego stanu znajdują się w sytuacji korzystniejszej z punktu widzenia realizacji podstawowych życiowych zadań chrześcijańskich. To zaś nasuwa pytanie o precyzyjnie ujętą rację takiego uprzywilejowania. Dokumenty soborowe dosłownie i bezpośrednio pytania tego nie stawiają, ani rzecz jasna, nie usiłują wprost na nie odpowiedzieć. Dostarczają jednak wartościowej przesłanki pozwalającej na rozwiązanie stojącej za tym pytaniem poważnej trudności. Przesłanką tą

12 „Ochrzczeni bowiem poświęcani są przez odrodzenie i namaszczenie Duchem Swiętym, jako dom duchowy i święte kapłaństwo, aby przez wszystkie właściwe chrześcijaninowi uczynki składać ofiary duchowe i głosić moc Tego, który wezwał ich z ciemności do swego prawdziwego światła (por. 1 P. 2, 4-10). Toteż wszyscy uczniowie Chrystusa, trwając w modlitwie i chwaląc wspólnie Boga (por. Dz. 2, 42-47), samych siebie składać mają na ofiarę żywą, świętą, miłą Bogu..." L. G. nr 10.

13 P. C. $\mathrm{nr} 5$.

14 „A Aby jednak móc otrzymać obfitsze owoce łaski chrztu, postanawia (chrześcijanin - zakonnik dop. S. N.) przez ślubowanie rad ewangelicznych w Kościele uwolnić się od przeszkód, które mogłyby go odwieść od żarliwej miłości i doskonałości kultu. Bożego, i jeszcze ściślej poświęca się służbie Bożej" L. G. nr 44.

15 „Członkowie wszystkich instytutów powinni to zwłaszcza sobie uświadomić..., iż żyją dla samego Bogá, umarłszy nie tylko dla grzechu (por. Rz. 6, 11) lecz także wyrzekłszy się świata" P. C. nr 5.

16 Przeciwne stanowisko zdaje się reprezentować jeden z komentatorów tego rozdziału L. G. R. Schulte, upatrujący specyfikę życia zakonnego w odzwierciedleniu życia Jezusa Chrystusa, żyjącego wyłącznie dla Boga. Por. La vie religieuse comme signe, w: L'Eglise de Vatican II, Paris 1966, t. III, 1155. 
jest eklezjalny wymiar powołania zakonnego. Zanim jednak przejdzie się do dokładniejszego omówienia tego wymiaru, trzeba dla pełności obrazu powołania zakonnego zasygnalizować pozostałe jego elementy składowe, jakimi są: naśladowanie Chrystusa i ściśle związany z nim radykalizm ewangeliczny razem z praktyką rad ewangelicznych.

Naśladowanie Chrystusa bardzo wyraźnie uznane zostało za jeden z bezspornych pierwiastków składowych powołania zakonnego. Sobór stwierdza to bez ogródek: „stan ten naśladuje wierniej i ustawicznie uprzytamnia w Kościele tę formę życia, jaką obrał sobie Syn Boży przyszedłszy na świat, aby czynić wolę Ojca i jaką zalecił uczniom, którzy za Nim poszli" ${ }^{17}$. W istocie życie zakonne jest dzisiaj nie do pojęcia bez elementu tego wierniejszego naśladowania Chrystusa ${ }^{18}$. Z jednej strony jest ono logiczną konsekwencją konsekracji w sensie chrześcijańskim, ze względu na fakt, że ta konsekracja jest właściwie przedlużeniem i partycypacją zbawczej tajemnicy Jezusa Syna Bożego. Stąd jest zrozumiałe, że rozwój i pełnia tej tajemnicy może się dokonywać tylko na drodze zjednoczenia z Chrystusem. To zaś warunkowane jest jego naśladowaniem polegającym i zmierzającym do jak najwierniejszego odtwarzania jego życia z całą jego specyfiką i niepowtarzalną odrębnością, której swoistą syntezę starowi duch rad ewangelicznych. W ten sposób zrozumiałym się staje miejsce rad ewangelicznych i związanych z nimi ślubów w życiu i powol̀aniu zakonnym. Stanowią one logiczną konsekwencję, czy od innej strony rzecz ujmując, wymóg faktu konsekracji i oddania się Bogu w i poprzez tajemnice Chrystusa, Wcielonego Słowa. Doskonała jej realizacja, która stanowi zadanie i przedmiot najgłębszej troski, budującego na zbawczym dziele Chrystusa, chrześcijanina.

Ten kolejny faktor struktury życia zakonnego, choć ukazuje się jako element jak najbardziej oczywisty i logiczny, pozostawia jedną poważna wątpliwość. Wiąże się ona z powszechnym przeznaczeniem i wezwaniem do życia radami ewangelicznymi 19. Jak powie J. M. Tillard: „Przyjmuje się obecnie, że wszyscy wierzący powołani są do doskonalej miłości i wszyscy mogá ją realizować w ich stanie, który dostarcza im także okazjji do życia głęboką rzeczywistością rad ewangelicznych" 20. Jeżeli jednak wszyscy powolani są do życia radami ewangelicznymi, to czy istnieje faktycznie, a jeżeli tak, na czym polega ta zakonna odrębność w tym względzie?

17 L. G. nr 44.

18 Por. J. Galot, Porteurs du souffle de l'Esprit, Paris s. 47: „Le Christ demeure l'unique nécessaire à l'intérieur de la vie religieuse elle - même".

19 Wyraźnie mówi o tym nr $42 \mathrm{~L}$. G., por. Mgr. Philips, L’Eglise et son mystère au deuxieme Concile du Vatican, t. II, Paris, 105-116.

${ }^{20}$ Les réligieux au coeur de l'Eglise, Paris 1969, 11. 
I w tym wypadku jak się zdaje, jedyny sposób znalezienia zadowalającej odpowiedzi stanowi odwolanie się do eklezjalnego wymiaru powołania zakonnego.

\section{EKLEZJALNY WYMIAR ZYCIA ZAKONNEGO}

Doniosłe znaczenie życia zakonnego w życiu i działalności Kościoła nigdy nie było poddawane w wątpliwość. Mniej lub bardziej wyraźniej zawsze zdawano sobie sprawę $\mathrm{z}$ tego, co tak dobitnie wyraził Pius XII w Konstytucji Provida Mater: „stan zakonny... pozostaje w ścisłej i szczególnej łączności z ostatecznym przeznaczeniem Kościoła, a mianowicie z uświęceniem, do którego musimy dążyć, używając skutecznych i właściwych środków" ${ }^{21}$. II Sobór Watykański tę "ścisłą i szczególną łączność nie tylko z ostatecznym przeznaczeniem Kościoła” ale z całym jego życiem i najgłębszą strukturą tak dobitnie stwierdził, że odtąd jeżeli „Kościół będzie chciał dokonać swego samookreślenia, nie będzie mógł tego dokonać bez wzmianki o zakonach" 22 .

Sobór jednak nie ograniczył się tylko do uroczystego stwierdzenia głębokiego zakotwiczenia życia zakonnego w strukturze Kościoła, ale wskazał konkretne sposoby urzeczywistnienia się tego zakotwiczenia.

Pierwszym z tych sposobów jest funkcja znaku symbolizującego i wyrażającego najgłębsze pokłady tajemnicy Kościoła i związanej z nią ściśle tajemnicy Chrystusa. Kościół, jako rzeczywistość na wskroś nadprzyrodzona, nie jest łatwy do zrozumienia w różnych swoich warstwach. Życie zakonne jest jedyną w swoim rodzaju ilustracją, zawariość tych właśnie jego warstw człowiekowi przybliżającą i co ważniejsze ku nim pociągającą ${ }^{23}$. Wyjątkowa wymowa tego symbolu polega na tym, że symbolizowana treść w nim samym się urzeczywistnia, co prawda w swoistej miniaturze, w postaci kiełkującego ziarna, tym niemniej realnie i adekwatnie adekwatnością ziarna i wyrastającego zeń kłosu. Jak powie lapidarnie Tillard: „w łonie całego Ludu Bożego będącego w pochodzie do Ojca, życie zakonne otrzymało od Ducha Sw. prorockie posłannictwo wyrażania w sposób egzystencjalny, że Królestwo Boże jest ju ż obecne między nami, że ostatnie dni już nadeszły, że wieczność w pewien sposób Wtargnęła ju $\dot{z}$ w historię" 24 .

21 AAS 40 (1947) 120.

22 Por. H. Volk, Christenstand - Ordenstand, w: Gesameltte Schriften, Mainz 1966, B. 2, 229: ,Somit ist dokumentiert dass, die Kirche in ihrer Selbstberschreibung nicht darauf verzichtet auch von dem Orden zu reden".

23 ,Jest więc ślubowanie i spełnianie rad ewangelicznych niejako widomym znakiem, który może i powinien pociągną́ skutecznie wszystkich członków Kościoła do ochoczego wypelniania powinności powołania chrześcijańskiezo" (L. G. nr 44).

24 Dz. cyt., 51. 
Tekst powyższy jest echem następującego doniosłego fragmentu Lumen Gentium, sankcjonującego życie zakonne w roli znaku eschatologicznego wymiaru Kościoła: ,Skoro bowiem Lud Boży nie ma tutaj trwałego miasta, lecz szuka przyszłego, to stan zakonny, który bardziej uwalnia swych członków od trosk ziemskich, w wyższym też stopniu tak ukazuje wszystkim wierzącym dobra niebiańskie już na tym świecie obecne, jak. i daje świadectwo nowemu i wiekuistemu życiu uzyskanemu dzięki odkupieniu Chrystusa, jak wreszcie zapowiada przyszle zmartwychwstanie i chwałę królestwa niebieskiego" 25 .

Ta funkcja znaku pełniona przez życie zakonne w Kościele, ma zastosowanie w drugiej jeszcze podstawowej warstwie rzeczywistości Kościoła, jaką jest tajemnica Chrystusa i jego zbawczego dzieła. Jak dosadnie wyrazi to Konstytucja o Kościele: ,Stan ten naśladuje wierniej i ustawicznie uprzytamnia w Kościcle tę formę życia, jaką obrał sobie Syn Boży przyszedłszy na świat, aby czynić wolę Ojca i jaka zalecił uczniom, którzy za nim poszli" 26 . W istocie życie zakonne z jego fundamentainą orientacją, jaką jest konsekwentne naśladowanie Chrystusa, pełniącego w swoim życiu niezmiennie wolę Bożą, wyraża, ale i urzeczywistnia to, co stanow: i cel główny, przedmiot troski i rację bytu tajemnicy Kościoła ${ }^{27}$. Stanow to nowy element ścisłych powiązań istniejących między Kościołem a stanem zakonnym.

Kolejnym elementem tych powiązań jest zaangażowanie powołania zakonnego w zbawczą działalność Kościoła. Sobór z całym naciskiem stwierdza, że życie praktykujących $w$ ramach powołania zakonnego rady ewangeliczne, "winno być poświęcone także dobru całego Kościoła" ${ }^{28}$. Niemniej dobitnie określa, w jaki sposób poświęcenie to ma się wyrazić: „Wynika stąd obowiązek pracy w miarę sił i stosowanie do formy osobistego powołania, bądź modlitwą, bądź gorliwym działaniem, celem zakorzenienia i umocnienia w duszach Królestwa Bożego i rozszerzania go na wszystkie kraje" 29. Komentując wnikliwie ten doniosły passus Konstytucji, J. Galot wskazuje najpierw na najgłębszą podstawę zawartej w niej zasady, którą upatruje po prostu w tym, że, życie radami ewangelicznymi z natury swojej poświęcone jest dobru Kościoła... to jest bowiem ostatecznie jego cel” ${ }^{30}$, po to, żeby zakończyć wymownym apelem: „oczekuje się więc od niego (zakonnika dop. S. N.) bardziej aniżeli od innych chrze-ścijan, że będzie posiadał zmysł Kościoła a cała jego egzystencja przeniknięta będzie pasją życia dla Kościola i gorącym pragnieniem jego

\footnotetext{
25 L. G. nr 45.

26 I. G. nr 45.

27 Por. R. Schulte, art. cyt., 1155

2 I. G. r. VI, nr 44 .

29 Tamze

: Les relinieux..., 86.
} 
wzrostu" s1. Ujęte w ten sposób fundamentalne ukierunkowanie życia zakonnego na dobro Kościoła i uczestnictwo w jego działalności zbawczej, ukazuje z całą oczywistością prawdę o jego ścisłym zakorzenieniu w życiu i strukturze Kościoła. Sobór jednak nie ogranicza się tylko do wskazania tych różnorakich powiązań, jakie istnieją między Kościołem a życiem zakonnym. W konstruowaniu katolickiej syntezy powołania stanu zakonnego, robi jeszcze jeden decydujący krok, stanowiący z jednej strony podsumowanie, ale $z$ drugiej wyjaśnienia od podstaw tych ścisłych powiązań. Krokiem tym jest usytuowanie życia zakonnego w charyzmatycznym wymiarze struktury Kościoła.

\section{CHARYZMATYCZNY CHARAKTER ZYCIA ZAKONNEGO}

Przystępując do omawiania tego doniosłego fragmentu soborowej doktryny o życiu zakonnym trzeba stwierdzić, że Sobór wyraźnie uchylił się od zastosowania do niego klasycznej nazwy charyzmatu. Miało to swoje źródło w chęci uniknięcia terminologii technicznej, kojarzącej się z pewnym stereotypem podręcznikowej teologii ${ }^{32}$. Tym niemniej nie pozostawia on miejsca na żadną wątpliwość, że życie zakonne uważa za teren szczególnego działania Ducha Sw., kształtującego w Kościele warstwę określaną mianem wymiaru charyzmatycznego jego struktury ${ }^{33}$.

Wielka to, a jakże nieznana część prawdy o Kościele. O ile porządek hierarchiczny Kościoła stanowi ucieleśnienie oblubieńczej miłości Chrystusa dla swojego oblubionego Kościoła, o tyle porządek charyzmatyczny urabia i wyraża miłość oblubienicy Kościoła wobec jego oblubicńca Chrystusa ${ }^{34}$. Choć i ten pierwszy nie pozostaje bez wpíywu Ducha Sw., to ten drugi jest jego domeną szczególna, by nie powiedzieć wyłączna. Wszak idzie o proces aplikacji zbawczego dzieła Chrystusa, o faktyczną realizacje zbawienia w konkretnych ludziach, której szczytowym momentem jest misterium uświçcenia duszy ludzkiej od pierwszego działania zbawiajacej laski, po wyżyny jej mistycznego zjednoczenia

31 J. W., 87.

32 Por. J. Galot, Les religieux dans l'Eglise, Paris 1966, 99. J. II. Tillard w tym niezbyt przejrzystym ujęciu roli Ducha Św. W życiu zakonnym upatruje wyraźny brak Dekretu. Por. art. cyt., 94-95.

33 Trzeba lojalnie zauwá̇yć, że stano wczym przeciwnikiem wyodrębniania a tym bardziej swoistego przeciwstariania w Kościele struktury hierarchicznej i charyzmatycznej jest Msgr. Philips, dz. cyt., 119. Polemizując z J. Galot przytacza on ważkie argumenty sprzeciw ten motywujące. Niemniej wydaje się, że argumentacja J. Galot jest o wiele bardziej przekonywująca. Opiera się ona na wnikliwej analizie natury charyzmatu w ogóle i na głębokim i stałym zapotrzebowaniu na niego w życiu Kościoła. Por. J. Galot, Les religieux dans l’Eglise, $155 \mathrm{nn}$. Philips zresztą nie jest przeciwny życiu zakonnemu jako specyficznej strukturze istniejącej w Kościele, byleby nie czynić z niej części struktury Kościoła jako takiej: ,Une expression plus correcte dirait donc que les religieux edifient une structure dans l'Eglise mais ne font pas partie de la.structure même de l'Eglise'. Tamże.

34 Por. G. Martelet, Dz. cyt., 102 nn. 
z Bogiem. Wiadomo zaś, że zbawienie ludzkie na tym etapie, w Duchu Swiętym ma swego głównego sprawcę i protektora ${ }^{35}$.

W powyższym świetle zrozumiałym się staje przekonanie o przynależności indywidualnego powołania zakonnego do porządku charyzmatycznego w Kościele ${ }^{36}$. Jako rzeczywistość jak najśsiślej związana ze sprawą realizacji zbawienia i świętości, musi być terenem stałej inicjatywy i działania Ducha Sw. Trzeba powiedzieć więcej: powołanie zakonre w Kościele jest darem Ducha Sw. dla otrzymującego go człowieka ale i dla samego Kościoła, w którego łonie przecież dokonuje się zbawienie i uświęcenie tego człowieka.

Pierwszy człon powyższego stwierdzenia nie budzi żadnych wątpliwości. Charyzmatyczność powołania zalronnego w wymiarze indywidualnego czlowieka narzuca się z całą cczywistością. Powiołanie to bowiem stanowi niewątpliwie owoc interwencji Ducha Sw., jest więc jego prawdziwym darem, a to jest pierwszym elementem składowym prawdziwego charyzmatu ${ }^{37}$. Jest jednak jeszcze drugi, a stanowi go przeznaczenie dla drugich, słowem charakter społeczny ${ }^{38}$. Nie ulega już dzisiaj dla nikogo wątpliwości, że poza fundamentalną orientacją zakonnika ku życiu we wspólnocie, poza troską o osobiste uświęcenie, powołanie nakłada na niego odpowiedzialność za efektywne zbawianie innych na drodze zaangażowania się $\mathrm{w}$ taką, czy inną inicjatywę $\mathrm{w}$ tym zakresie ${ }^{39}$. Istnieją więc bezsporne dane do tego, by $\mathrm{w}$ indywidualnie rozumianym powołaniu zakonnym dojrzeć klasyczny charyzmat.

Równie mocne, choć może nie tak oczywiste są przesłanki uzasadniające charakter powołania zakonnego jako odrębnej i swoistej struktury Kościoła i jego życia. Potwierdza to doktryna Soboru, która życie zakonne tak $w$ jego początkach, jak i historycznym trwaniu ukazuje jako bezsporny skutek działania Ducha Sw., określany tradycyjnie mianem charyzmatu.

„Już od początku byli w Kościele zarówno mężczyźni jak i niewiasty, którzy chcieli przez praktykę rad ewangelicznych z większą swobodą iść

35 Por. Y. Congar, Esquisses du Mystere de l'Eglise, Paris 1953, 134-146; H. Mühlen, L'Esprit dans l'Eglise, Paris 1969, t. II, 302 nn; G. Martelet, dz. cyt., 77-90; J. Galot, Porteurs..., 60-62; K. Rahner, Eléments dynamiques dans l'Eglise, Paris $1967, \quad 39-74$.

36 Por. P. C. nr 1; J. Galot, Les religieux..., 99-101; Porteurs..., 7-16; G. Martelet, j. w., 93-107; J. M. R. Tillard, art. cyt., 94 nn.

37 Por. J. Gslot, Porteurs..., 20; H. Schirmann, Les charismes spirituels, w. L'Eglise de Vatican II, Paris 1967, t. II, 544.

38 Por. H. Schürmann, j. W.

39 Por. L. G. nr 44 ,A ponieważ rady ewangeliczne przez miłość, do której prowadzą w szczególny sposób zespalają z Kościołem i jego tajemnicą tych, którzy za nim idą, przeto życie ich duchowe winno być poświęcone także dobru całego Kościola. Wynika stąd obowiązek pracy..., celem zakorzenienia i umocnienia w duszach Królestwa Bożego..."; P. C. r. I, nr 1, 5; G. Philips, dz. cyt., 126-127; J. Galot, Porteurs..., 35-37. 
za Chrystusem i wiernie Go naśladować, prowadząc na swój sposób życie Bogu poświęcone. Wielu spośród nich z natchnienia Ducha Św. (podkr. S. N.) prowadziło życie pustelnicze lub tworzyło rodziny zakonre, które Kościół chętnie objął swą powagą i zatwierdził" ${ }^{40}$ - oto w jaki sposób Dekret ujmuje zaangażowanie Ducha Sw. w pojawienie się zwłaszcza zorganizowanej postaci życia zakonnego w łonie chrześcijańsiwa. Nie inaczej rzecz wygląda przy opisie procesu kształtowania się i dojrzałego istnienia zakonów w życiu Kościoła: „W ten sposób... powstała przedziwna rozmaitość wspólnot zakonnych, która... przyczyniła się do tego, że Koúciół... ołazuje się ozdobiony różnymi darami swoich dzieci... W tak wielkiej zaś różnorodności darów wszyscy ci, co przez Boga wzywani są do praktykowania rad ewangelicznych... w szczególny sposób poświęcają się Panu idąc za Chrystusem... Tak pobudzeni miłością r o zla ną przez Ducha Sw. W ich sercach (podkr. S. N.) coraz bardziej żyją dla Chrystusa i dla Jego Ciała, którym jest Kościól” "11. Jak słusznie zauważa komentujący powyższy fragment J. Galot: „Chodzi o dar duchowy, o impuls, który przychodzi z dołu, z łona Ludu Bożego, realizuje się bowiem w zwyczajnych członkach Kościoła, interwencja zaś władzy kościelnej pod postacią zgody i potwierdzenia przychodzi potem. Poryw ten krystalizuje się w stałych sposobach życia i działania, w rozwoju pewnej stałej, bogato zróżnicowanej struktury życia zakonnego. Rezultat tego jest „,przedziwny”, godny działania Ducha Sw." 42.

Baczna więc obserwacja i analiza wewnętrznej dialektyki życia zakonnego w Kościele, pozwala bez trudu odkryć jego Autora, charakteryzującego się specyficznym sposobem i specyficznym terenem działania. W istocie, gdy przypomnieć sobie wielkich założycieli zakonów od świętych Pachomiusza, Benedykta, Augustyna, Franciszka, Dominika, Ignacego, Wincentego, Teresy, czy bliższych nam św. Jana Bosko, br. Alberta, czy O. Honorata, gdy zastanowić się nad zapałem, różnorodnością zaangażowań i ogromem dokonanego $\mathrm{w}$ założonych przez nich rodzinach zakonnych dobra, to nie można mieć wątpliwości kogo uznać trzeba za ostatecznego Inicjatora tego wszystkiego.

Ale ten pobieżny nawet rzut oka na rolę i znaczenie życia zakonnego w Kościele, ukazuje nie tylko to, że stanowi ono dzieło Ducha Św., ale i to, że jest to dzieło ogromne, rozdział w życiu i strukturze Kościoła, bez którego nie sposób sobie wyobrazić ani jednego ani drugiego, jak nie można ich sobie wyobrazić bez porządku charyzmatycznego. Porządek charyzmatyczny bowiem jest darem Ducha Sw. dla założonego przez Chrystusa Kościoła, ale darem niezbędnym, który zawsze w Kościele był

\footnotetext{
40 P. C. nr 1.

41 Tamże.

42 Porteurs..., 20
} 
i zawsze będzie ${ }^{43}$. Przynależąc więc do tego porząaku w Kościele, życie zakonne jako prawdziwy dar charyzmatyczny przeznaczony jest dla całego Kościoła, dla jego ustawicznego wzrostu, dla pełnej realizacji wyznaczonych mu zadań, które streszczają się w jednym, naczelnym, a jest nim sprawa zbawienia i uświęcenia ${ }^{44}$. To ona stanowiła sprężynę, która podyktowała powołanie do życia tej dziwnej i jak widzieliśmy chwilami niezrozumiałej w pełni kościelnej struktury.

Ujmowane $\mathrm{w}$ ten sposób życie zakonne, rozwlewa wspomniane wyżej trudności o nieusprawiedliwionym uprzywilejowaniu zakonników w płaszczyźnie chrześcijańskiego przeznaczenia do świętości i środków do niej prowadzących. Życie zakonne jest niewątpliwie jakimś uprzywilejowaniem $\mathrm{w}$ jednej i drugiej płaszczyźnie, bo jest przecież darem, dobrem otrzymanym od Ducha Sw., ale jest to dobro, które przeznaczone jest dla całego Kościoła realizującego program skutecznego uświęcenia swoich członków. W ten sposób jest ono nieustannym wezwaniem i przypomnieniem, jest znakiem i przykładem determinacji w dążeniu do świętości i umiejętności w doborze środków umożliwiających jej osiągnięcie, jest żywą ilustracją ducha i programu ewangelii. Czyni to z niego swoistego rodzaju miniaturę Kościoła, realizującą jego podstawowe przymioty jakimi są: sł̉użba sprawie uświęcenia, wspólnotowy rytm jego urzeczywistniania, totalne oddanie Bogu i jego chwale.

Nakreślony obraz zaangażowania Ducha Św. w strukturę życia zakonnego, ukazuje od jednej jeszcze strony jego głębokie powiązania z tâjemnicą Kościoła. Wymiar charyzmatyczny życia zakonnego jednak w wyjątkowo jaskrawy sposób ukazuje to, co można by było nazwać swoistym sprzężeniem zwrotnym między nim a rzeczywistością Kościoła. Istotę jego stanowi fakt, że pełne i zadowalające ujęcie istotnej treści życia zakonnego jest możliwe tylko pod warunkiem jego usytuowania w strukturze i życiu Kościoła. Ale i tajemnica Kościoła z jego fundamentalnym przeznaczeniem, żeby służyć sprawie rzeczywistego uświęcenia ludzi, posiada w rzeczywistości życia zakonnego wymowne ucieleśnienie, nieustanne wezwanie, a nade wszystko niezawodny sprawdzian świadczący o tym, że stanowiące sens jego istnienia dzieło świętości jest realizowane $i$ to realizowane jako najwyższe i jedyne zadanie życia, a więc tak, jak realizowane w Kościele być powinno.

43 Por. Y. Congar, Esquisses..., 164 nn; R. Schnackenburg, Die Kirche im Neuen Testament, Leipzig 1961, 141-146; H. Mühlen, L' Esprit dans l'Eglise, Paris 1969, t. I, $428 \mathrm{nn}$.

${ }_{44}$ Por. J. Galot, dz. cyt., 21. 


\section{SUR LA THÉLCGIE DE LA VIE RELIGIEUSE}

\section{R E $\mathbf{S} \mathbf{U} \mathbf{M} \overline{\mathbf{E}}$}

Pour bien connaitre le vie religieuse, renouvelée et revalorisé par le Concile, il faut absolument la replacer dans le contexte du mystêre de l'Eglise. La codification conciliaire de la doctrine catholique dans la vie religieuse apporte des éléments de valeur qui permettent d'aboutir à une synthèse persuasive, laquelle aide à se référer justement à la mesure ecclésiale de la vie religieuse. Or, cette mesure constitue le signe symbolique, partıculièrement lisible, de deux couches essentielles de la réalité de l'Eglise, à savoir le fait que se concrétise en elle le Royaume eschatologique de Dieu et le mystère du Verbe Incarné. En outre, le vie religieuse symbolise et exprime exceptionnellement bien le destin apostolique de l'Eglise. Cette triple liaison entre le mystère de l'Eglise et la vie religieuse synthétise et élucide nettement son appartenance à la dimension charismatique de l'Eglise. Cette appartenance est prouvée par la liaison organique de la vie religieuse avec le processus de sanctification de l'homme, processus dans lequel est engagé le Saint Esprit, l'attitude sociale de la vie monacale qui est, comme un véritable charisme, un don aux autres; mais elle est surtout prouvée par la dialectique spécifique du fonctionnement propre à celui de la structure charismatique de l'Eglise. Or, celle-ci se caractérise par la ferveur, la diversité et la faculté de prendre des initiatives. 